\title{
Rumen fermentation and rumen microbes in Nellore steers receiving diets with different lipid contents ${ }^{1}$
}

\section{Juliana Duarte Messana ${ }^{2}$, Telma Teresinha Berchielli ${ }^{2}$, Pedro Braga Arcuri ${ }^{3}$, Ricardo Andrade Reis $^{2}$, Roberta Carrilho Canesin ${ }^{2}$, Andressa Ferreira Ribeiro², Giovani Fiorentini², Juliano José de Resende Fernandes ${ }^{4}$}

\author{
1 Project financed by Fundação de Amparo à Pesquisa do Estado de São Paulo (FAPESP). \\ 2 Departamento de Zootecnia, Universidade Estadual Paulista /Campus Jaboticabal, Brazil. \\ ${ }^{3}$ Embrapa Centro Nacional de Pesquisa de Gado de Leite. \\ ${ }^{4}$ Departamento de Produção Animal, Universidade Federal de Goiás (UFG), Goiânia, Goiás, Brazil.
}

\begin{abstract}
The objective of the present study was to evaluate the effects of dietary lipid content (20, $40 \mathrm{and} 60 \mathrm{~g} / \mathrm{kg}$ dry matter) on intake, total and ruminal apparent digestibility of dry matter (DM), nutrient digestibility, rumen fermentation parameters, microbial synthesis efficiency and rumen microbial content of beef cattle. Nine cannulated steers at 6 months of age with initial body weight of $232 \pm 35 \mathrm{~kg}$ were used in a triplicate $3 \times 3$ Latin square design. The results indicated that the total intake and digestibility of DM, organic matter (OM), gross energy (GE), neutral detergent fiber (NDF) and acid detergent fiber (ADF) were not affected by the lipid content of the diet. However, the lowest lipid content diet reduced the total digestibility of crude protein $(\mathrm{CP})$ and total carbohydrate linearly compared with the highest lipid diet. In contrast, when steers were fed a diet containing $20 \mathrm{~g}$ lipids $/ \mathrm{kg}$ of DM, the concentration of ammonia in the rumen decreased quadratically relative to the other diets. Ruminal $\mathrm{pH}$ was not affected by the interaction of treatment and sampling time; however, the rumen $\mathrm{pH}$ decreased quadratically in animals that received the highest dietary lipid content $(60 \mathrm{~g} / \mathrm{kg})$ compared with animals that received 20 and $40 \mathrm{~g}$ lipids/ $\mathrm{kg}$ of DM. The rumen concentrations of volatile fatty acids, propionate, and butyrate and the acetate/propionate ratio were affected by the dietary lipid content. However, the microbial population, microbial N flow, and efficiency of synthesis were not affected by dietary lipid content. Overall, an increase in the lipid content of the diet of Nellore steers resulted in similar digestive profiles and fermentation conditions.
\end{abstract}

Key Words: bovines, digestibility, fat, soybean, volatile fatty acids

\section{Introduction}

Foods with high lipid contents can be added to the diets of highly productive animals to satisfy their high energy requirements. Moreover, an appropriate balance between structural and non-structural carbohydrates in the diet and the optimal use of digestible energy can be attained by increasing the dietary lipid content (Hess et al., 2008; Weiss \& Pinos-Rodriguez, 2009).

Several studies have investigated the effects of feeding different lipid sources at various levels, and the results show that, in high doses, unsaturated lipid supplements can have toxic effects on gram-positive bacteria in the rumen, especially the cellulolytic population (Nagaraja et al., 1997). High unsaturated lipid supplementation can also reduce the degradability of fiber by microbes (Harvatine \& Allen, 2006) and ammonia production (Eifert et al., 2006). Thus, when supplying unsaturated lipids to ruminants, the effects on the ingestion and digestion of nutrients must be evaluated to achieve the desired production level (Jenkins \& McGuire, 2006; Relling \& Reynolds, 2007).

It is well recognized that vegetation containing unsaturated fatty acids has the potential to inhibit ruminal fermentation. However, this inhibition may also be attributed to the level of dietary fat, and the optimal levels of unsaturated fatty acids in the diet are unknown. Some authors, such as Zinn et al. (2000), Weiss \& Pinos-Rodriguez (2009) and Hess et al. (2008), report that levels higher than 50 and $60 \mathrm{~g}$ lipids $/ \mathrm{kg}$ of DM in DM fat supplements affect the DM intake, while others, such as NRC (2001) Ueda et al. (2003), and Harvatine \& Allen (2006), report that up to $30 \mathrm{~g}$ lipids $/ \mathrm{kg}$ of DM diet can be used with minimal negative effects on microbial growth and rumen function. These results indicated that the effects of unsaturated fatty acids on ruminal fermentation could be variable because of the lipid levels and basal diet composition. In this study, the authors hypothesized that the increase in dietary lipid levels ( $>30 \mathrm{~g} / \mathrm{kg}$ of DM) would decrease feed intake, rumen 
fermentation and ruminal digestibility compared with the lower lipid levels (20 g/kg of DM).

Thus, the objective of this study was to evaluate the effect of the dietary soybean unsaturated lipid content on the intake, total and partial digestibility of DM and nutrients, fermentation parameters $(\mathrm{pH}$, ammonia nitrogen, and volatile fatty acids), efficiency of microbial synthesis and rumen microbial content in beef cattle.

\section{Material and Methods}

The experiment was conducted at Setor de Avaliação de Alimentos e Digestibilidade of Departamento de Zootecnia da Faculdade de Ciências Agrárias e Veterinárias - UNESP, Campus Jaboticabal, São Paulo, Brazil. Nine castrated Nellore steers cannulated in the rumen and in the duodenum were subjected to a triplicate $3 \times 3$ Latin square design. The steers were 16 months old and presented an initial average body weight of $232 \pm 35 \mathrm{~kg}$. The experimental period duration was 22 days, including 15 days of adaptation and 7 days of sample collection.

Experimental diets were formulated to meet or exceed animal nutritional requirements according to the Cornell Net Carbohydrate and Protein System (CNCPS), version 5.0 (Fox et al., 2003).

The following treatments were evaluated: no-soybean diet, with $20 \mathrm{~g} / \mathrm{kg}$ of ether extract in the DM; diet containing $120 \mathrm{~g} / \mathrm{kg}$ diet of raw ground soybean, with $40 \mathrm{~g} / \mathrm{kg}$ of ether extract in the DM; and diet containing $230 \mathrm{~g} / \mathrm{kg}$ diet of raw ground soybean, with $60 \mathrm{~g} / \mathrm{kg}$ of ether extract in the DM

Table 1 - Percentage of ingredients and chemical composition of the diets

\begin{tabular}{|c|c|c|c|}
\hline \multirow{2}{*}{ Item } & \multicolumn{3}{|c|}{ Lipid level in the diet $(\mathrm{g} / \mathrm{kg})$} \\
\hline & 20 & 40 & 60 \\
\hline \multicolumn{4}{|l|}{ Ingredient, g/kg DM } \\
\hline Corn silage & 500 & 500 & 500 \\
\hline Citrus pulp & 280 & 260 & 240 \\
\hline Soybean grain & 0.0 & 120 & 230 \\
\hline Soybean meal & 190 & 90 & 0.0 \\
\hline Mineral supplement ${ }^{1}$ & 30 & 30 & 30 \\
\hline \multicolumn{4}{|l|}{ Chemical composition } \\
\hline Dry matter, $\mathrm{g} / \mathrm{kg}$ & 637.4 & 637.6 & 637.8 \\
\hline Organic matter, g/kg DM & 916.0 & 918.1 & 920.0 \\
\hline Crude protein, g/kg DM & 149.1 & 146.8 & 143.4 \\
\hline Ether extract, g/kg DM & 19.3 & 42.3 & 63.2 \\
\hline Neutral detergent fiber, g/kg DM & 335.6 & 332.6 & 329.6 \\
\hline Acid detergent fiber, g/kg DM & 221.1 & 218.6 & 216.0 \\
\hline Lignin, g/kg DM & 27.2 & 26.7 & 26.3 \\
\hline Total digestible nutrients ${ }^{2}, \mathrm{~g} / \mathrm{kg} \mathrm{DM}$ & 700.9 & 715.6 & 701.2 \\
\hline Gross energy, Mcal/kg DM & 4.2 & 4.3 & 4.4 \\
\hline
\end{tabular}

(Table 1). All diets were fed once a day at $07 \mathrm{~h} 30$, and water was supplied ad libitum. The amount of feed offered was adjusted daily to obtain approximately $10 \%$ orts (as-fed basis).

The forage and concentrate supplied to the steers and the orts from each feeding were weighed daily to estimate individual intake. Samples of the supplied feed were collected and frozen for subsequent chemicalbromatological analysis.

To determine the apparent digestibility in the total digestive tract, total feces were collected from each animal separately at $07 \mathrm{~h} 00$, weighed, homogenized and sampled (500 g). The sampling and weighing of feces began 24 hours after feeding. The fecal samples were collected, stored in plastic bags and frozen until the end of the collection period. To determine the partial digestibility, $300 \mathrm{~mL}$ samples of digested matter in the duodenum were collected over two days (on the 2nd and 3rd days) at 6-hour intervals. The collection was delayed by 3 hours on the second day to ensure that a 24-hour period was accurately represented (Oliveira et al., 2007a).

To determine the daily flow of DM in the duodenum, the indigestible NDF (iNDF) content was used as a digesta marker (Harvatine \& Allen, 2006). The iNDF was obtained in situ after 144 hours of incubation (Berchielli et al., 2000).

To evaluate the fermentation parameters, samples of rumen fluid were manually collected before the diet was supplied (time zero) and at 2, 4, 8, and 12 hours post-feeding. Shortly after collection, the $\mathrm{pH}$ of the rumen fluid was determined with a digital $\mathrm{pH}$ meter (ORION 710A, Boston, MA), and a $2 \mathrm{~mL}$ aliquot of the fluid was placed in a plastic flask and frozen at $-20{ }^{\circ} \mathrm{C}$ for subsequent analysis of the volatile fatty acids (VFA). The VFA were evaluated according to the method adapted by Erwin et al. (1961) using gas chromatography. A $40 \mathrm{~mL}$ aliquot of rumen fluid was used to analyze the ammoniacal nitrogen content $\left(\mathrm{NH}_{3}-\mathrm{N}\right)$ according to the methodology adapted by Fenner (1965).

To determine the microbial composition in the rumen, $2 \mathrm{~L}$ of rumen content were collected from each animal on the 19th day of each experimental period to isolate bacteria (Cecava et al., 1990). Purine bases were used as microbial markers, and the bacteria and duodenal matter were measured according to the procedure described by Zinn \& Owens (1986), with modifications as proposed by Ushida et al. (1985). The quantity of microbial compounds in the duodenum was determined by dividing the N-RNA flow in the duodenum by the total N-RNA (the total-N ratio of the bacteria isolated from the rumen). Thus, the flow of DM and microbial protein in the duodenum was successfully quantified. 
Feeds, feces and orts samples were analyzed for $\mathrm{N}$ (AOAC Official Method 984.13), ash (AOAC Official Method 942.05) and ether extract (AOAC Official Method 920.39) in accordance with guidelines of AOAC (1995). The concentrations of NDF and ADF were determined using the method proposed by Van Soest et al. (1991), with samples digested for $40 \mathrm{~min}$ at $110{ }^{\circ} \mathrm{C}$ and $50.7 \mathrm{kPa}$ in an autoclave (Senger et al., 2008). The NDF analysis was performed in the presence of $\alpha$-amylase, and sodium sulfite was not used. In addition, the concentration of $\mathrm{N}$ in the residual material from the NDF and ADF analyses was determined to calculate the nitrogen fraction of the fiber. The acid detergent lignin (ADL) was determined according to Goering \& Van Soest (1970).

The gross energy (GE) content was obtained by combusting samples in an adiabatic bomb calorimeter (PARR Instrument Company 6300, Illinois, USA), and the digestible energy content (DE) was obtained from the digestibility coefficient of GE.

To analyze the rumen microbes, samples of the rumen content were collected one hour after the feed was supplied (Fluharty et al., 1996). The rumen content was transferred to thermoses and immediately taken to the Animal Nutrition Laboratory of FCAV/UNESP Jaboticabal. In the laboratory, the samples were diluted with an anaerobic solution (ADS, Bryant \& Burkey, 1953), homogenized under an atmosphere of $\mathrm{CO}_{2}$, and sequentially diluted $\left(10^{-2}\right.$ to $\left.10^{-12}\right)$. The analysis was conducted in triplicate, and aliquots of each sample were incubated in test tubes containing half of the selected culture prepared under anaerobic conditions. Successive dilutions $\left(10^{-2}\right.$ to $\left.10^{-4}\right)$, of the rumen content were performed to estimate the most probable number (MPN) of fungi (Gordon \& Phillips, 1998), and antibiotics were used (700 UI of streptomycin sulfate and 1600 UI of penicillin sodium) to inhibit bacterial growth in the medium. To quantify the bacterial population, successive dilutions were performed (to $10^{-12}$ ), and the microbes were inoculated at $39{ }^{\circ} \mathrm{C}$ in a complex medium containing soluble sugars and cellulose as a source of carbon and energy (Dehority et al., 1989). To estimate the MPN (Alexander, 1982) of bacteria, sequential dilutions of $10^{-10}$ to $10^{-12}$ were performed. After inoculation, the tubes used to estimate the bacterial and fungal contents were incubated at $39{ }^{\circ} \mathrm{C}$ for up to 7 days. Visual confirmation of growth was performed by determining the turbidity of the tubes (in triplicate), measuring the $\mathrm{pH}$, and recording the growth count and average value per treatment.

The protozoa were quantified by performing direct counts with a Sedgewick Rafter chamber (Dehority et al., 1989). The counts were obtained from aliquots of the rumen content, which were preserved in formol, a solution of water and an equal volume of $37 \%$ formaldehyde. In the direct count, the samples were diluted with $20 \%$ glycerol and stained with Lugol (D'agosto \& Carneiro, 1999).

The intake, coefficient of digestibility, microbial population (bacteria, fungi, and protozoa) and microbial protein synthesis data were analyzed as triplicate $3 \times 3$ Latin square data using the MIXED procedure of SAS (Statistical Analysis System, version 9.0). The model included a fixed effect for diet and random effects for steer and period.

The general mathematical model was represented by:

$$
\mathrm{Y}_{\mathrm{ijkl}}=\mu+T_{i}+P_{j}+T P_{i j}+e_{i j}
$$

where $\mathrm{Y}_{\mathrm{ij}}$ is the dependent variable, $\mu$ is the overall mean; $T_{i}$ is the $i$-th effect of the treatment or diet; $P_{j}$ is the $j$-th effect of the period; $T P_{i j}$ is the effect of the interaction between treatment $i$ and period $j$; and $e_{i j}$ is the residual experimental error (Tempelman, 2004). In the statistical model, normally and independently distributed errors were assumed $(0, \mathrm{~s} 2)$.

Ruminal $\mathrm{pH}$, VFA and ammonia $\mathrm{N}$ data were analyzed as triplicate $3 \times 3$ Latin squares data with repeated measures over time. The model included fixed effects for diet, time and the interaction between these 2 variables and random effects for steer and period. Linear and quadratic orthogonal contrasts were tested using the contrast statement of SAS with coefficients estimated based on the lipid levels. The effects of the factors were declared significant at $\mathrm{P}<0.05$, and trends were discussed at $\mathrm{P}<0.10$.

\section{Results and Discussion}

The ingestion of DM and nutrients except for EE was not affected $(\mathrm{P}>0.05)$ by the lipid content (Table 2). These results are contradictory to the observations of Hess et al. (2008) and Weiss \& Pinos-Rodriguez (2009), who demonstrated that lipid supplementation greater than $5 \%$ decreased the dry matter intake (DMI), canceling the effect of the energy concentration and resulting in no net increase in energy intake. Differences in the relationship between the diet and the NDF and ADF ingestion were not observed, which suggested that the tested lipid contents did not impair the performance of the microorganisms involved in degradation of fibrous components.

According to Jenkins \& McGuire (2006), the main effects of the addition of lipids on intake reduction are related to modifications in rumen fermentation. Specifically, a reduction in the digestibility of fiber in the rumen leads to an increase in the retention time of the NDF, which results in greater rumen fill. However, the forage to concentrate ratio $(\mathrm{F}: \mathrm{C})$, the type of functional groups, the degree of saturation of the lipids, the formation of carboxylate salts 
Table 2 - Intake of dry matter and nutrients and adjusted regression equations for steers fed different lipid contents

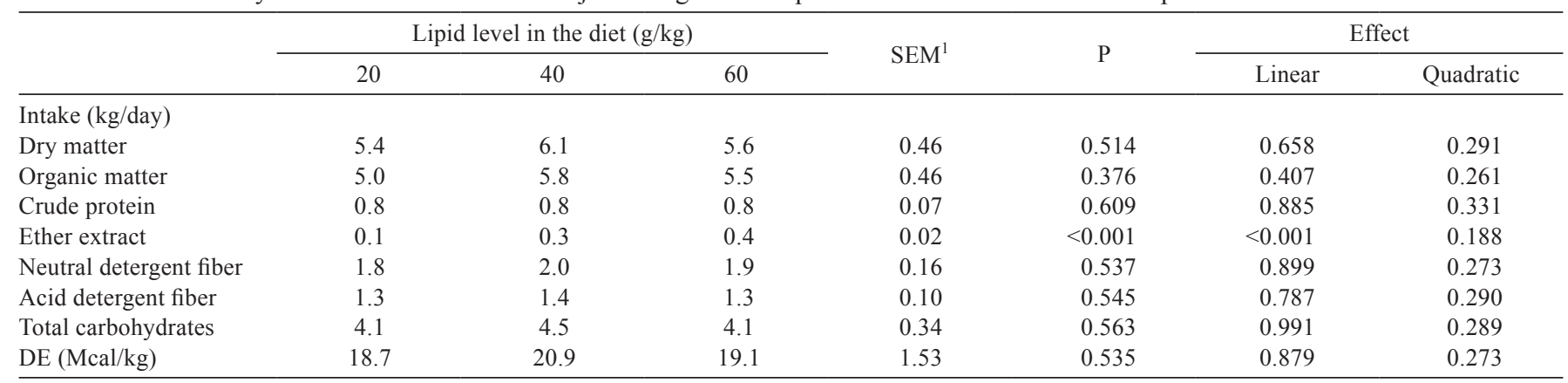

9 steers/treatment.

DE - digestible energy.

${ }^{1}$ Pooled standard error of treatment means.

and physical associations with the surface of feed particles and microorganisms affect the antimicrobial properties of the lipids (Ueda et al., 2003; Weiss \& Pinos-Rodriguez, 2009). The forage to concentrate ratios (F:C) used in the present study (basal diet with $500 \mathrm{~g} / \mathrm{kg} \mathrm{DM}$ of corn silage) may be responsible for the absence of an effect on the intake of nutrients and dry matter.

Another factor that affects the relationship between the diet and fibrous fraction (NDF and ADF) intake is forage quality. The corn silage used in the present study contained low amounts of unavailable components (41.6 lignin $\mathrm{g} / \mathrm{kg}$ of the DM and 103.6 carbohydrate fraction $\mathrm{C} \mathrm{g} / \mathrm{kg}$ of the $\mathrm{DM})$. Thus, the forage did not limit the DM intake or the action of ruminal microorganisms.

According to Zinn \& Plascencia (2002), when fat intake exceeds $0.96 \mathrm{~g} / \mathrm{kg}$ of body weight, the energy value of the lipids diminishes due to a decrease in the DMI. In the current study, the intake of lipids per body weight $(\mathrm{g} / \mathrm{kg})$ was $0.47,1.16$, and $1.59 \mathrm{~g}$. However, no response correlated to the energy value of the lipids was observed in the present study, which suggests that chemostatic mechanisms were not responsible for intake limitations.

Overall, the digestibility coefficients were not significantly different among treatments (Table 3). However, the digestibility coefficients of the ether extract of the diets evaluated increased linearly $(\mathrm{P}<0.05)$ as the concentration of lipids in the diet increased (804.60 to $926.30 \mathrm{~g} / \mathrm{kg}$ of the DM). Nevertheless, the total tract digestibility of crude protein and total carbohydrates tended to decrease with an increase in the lipid content of the $\operatorname{diet}(\mathrm{P}=0.063 ; \mathrm{P}=0.082$, respectively).

The total digestibility of ether extract increased with an increase in the lipid content of the diet because the lipid content increased the degree of non-saturation, which enhances the digestibility of fatty acids (Jenkins et al., 2008; Duckett \& Gillis, 2010).
Fatty acids (FA) in feeds are not oxidized or significantly degraded by ruminal microorganisms. However, the results of various studies have demonstrated that fatty acids disappear from the rumen when the lipid content of the diet is increased. According to Harvatine \& Allen (2006), variations in reported rumen FA losses may occur due to bacterial FA synthesis, especially in low-FA diets. Bacteria incorporate dietary FA into their plasma membranes, and bacterial FA cannot be attributed entirely to microbial production, so the true FA digestibility values occasionally reported in the literature have little meaning. Simple digestion studies cannot partition duodenal FA flow into dietary and microbially synthesized fractions, limiting the ability to determine the extent of rumen FA synthesis and digestion. Demeyer \& Doreau (1999) pooled data from five studies and estimated that the bacteria may contribute with up to $170 \mathrm{~g} / \mathrm{kg}$ of the lipids flowing from the rumen in animals fed a corn silage diet.

Several authors have reported that the supply of high quantities of lipids may interfere in total fiber digestibility. However, the results obtained in the present study are contradictory to those obtained by Oliveira et al. (2007b), who evaluated the effects of different sources of lipids (soybean oil and soybean) on intake, digestibility, and urea nitrogen in the plasma of feedlot-finished buffalo calves. The authors observed that the inclusion of soybean oil as an energy source caused a reduction in the intake and the digestibility of the fibrous fractions. Similarly, Zinn et al. (2000) found that the digestibility of the NDF fraction of a diet with a high fat content $(60.0 \mathrm{~g}$ yellow fat $/ \mathrm{kg}$ of DM in a diet containing $880.0 \mathrm{~g} / \mathrm{kg}$ of DM concentrate and $76.3 \mathrm{~g} / \mathrm{kg}$ of DM ether extract) was lower than the control diet $(20.0 \mathrm{~g} / \mathrm{kg}$ of the DM yellow fat and $37.4 \mathrm{~g} / \mathrm{kg}$ of the $\mathrm{DM}$ ether extract) in feedlot-finished steers.

In contrast, Hussein et al. (1995) did not observe any effects on the total digestibility of fiber in steers fed diets 
without canola, diets with $100 \mathrm{~g} / \mathrm{kg}$ of DM whole canola treated with alkaline hydrogen peroxide (partially protected fat), $100 \mathrm{~g} / \mathrm{kg}$ of DM ground canola (non-protected fat) and two different levels of forage content (700 and $300 \mathrm{~g} / \mathrm{kg}$ ).

High dietary levels of polyunsaturated fatty acid (PUFA) may inhibit bacterial growth in the rumen. However, the level of dietary PUFA in the current study may not have been detrimental to microbes and diet digestibility because the basal diet contains $500 \mathrm{~g} / \mathrm{kg}$ of corn silage. Jenkins (1993) and Ueda et al. (2003) observed that diets with high forage-to-concentrate ratios may reduce the effects of PUFA on ruminal fermentation because the high fiber concentration promotes ideal conditions for the rapid growth of the microorganisms responsible for the hydrolysis and biohydrogenation of PUFA.
The average ruminal $\mathrm{pH}$ values (Table 4 ) were not affected by the interaction $(\mathrm{P}=0.269)$ between treatment and sampling time. However, in animals that received the highest dietary lipid content $(60 \mathrm{~g} / \mathrm{kg})$, rumen $\mathrm{pH}$ decreased quadratically $(\mathrm{P}<0.001)$ with an increase in the lipid content. The diet with the highest lipid content presented the lowest $\mathrm{pH}$ (6.4). However, in all of the diets, the ruminal $\mathrm{pH}$ remained above 6.3; thus, the $\mathrm{pH}$ did not have a significant effect on ruminal fermentation. Russell \& Wilson (1996) and Mertens (1997) reported that $\mathrm{pH}$ levels greater than 6.2 do not affect ruminal fermentation.

According to DeVeth \& Kolver (2001), the NDF digestibility was reduced when the ruminal $\mathrm{pH}$ remained below 6.0 for 4 hours. Moreover, microbial synthesis was significantly reduced when the $\mathrm{pH}$ remained below 6.0

Table 3 - Average values of apparent total and ruminal tract nutrient digestibility in steers fed different lipid contents, with adjusted regression equations

\begin{tabular}{|c|c|c|c|c|c|c|c|}
\hline & \multicolumn{3}{|c|}{ Lipid level in the diet $(\mathrm{g} / \mathrm{kg})$} & \multirow{2}{*}{ SEM $^{1}$} & \multirow{2}{*}{$\mathrm{P}$} & \multicolumn{2}{|c|}{ Effect } \\
\hline & 20 & 40 & 60 & & & Linear & Quadratic \\
\hline \multicolumn{8}{|c|}{ Total apparent digestibility, $\mathrm{kg} / \mathrm{kg}$} \\
\hline Dry matter & 0.723 & 0.722 & 0.700 & 1.69 & 0.389 & 0.243 & 0.500 \\
\hline Organic matter & 0.747 & 0.756 & 0.735 & 1.70 & 0.538 & 0.536 & 0.371 \\
\hline Crude protein & 0.708 & 0.691 & 0.663 & 1.94 & 0.161 & 0.063 & 0.778 \\
\hline Ether extract & 0.801 & 0.909 & 0.926 & 1.54 & $<0.001$ & $<0.001$ & $<0.001$ \\
\hline Neutral detergent fiber & 0.566 & 0.566 & 0.550 & 3.17 & 0.864 & 0.648 & 0.793 \\
\hline Acid detergent fiber & 0.541 & 0.548 & 0.508 & 2.94 & 0.362 & 0.281 & 0.373 \\
\hline Digestible energy & 0.725 & 0.723 & 0.694 & 1.74 & 0.225 & 0.131 & 0.430 \\
\hline \multicolumn{8}{|c|}{ Ruminal digestibility, $\mathrm{kg} / \mathrm{kg}$} \\
\hline Dry matter ${ }^{2}$ & 0.842 & 0.870 & 0.861 & 2.07 & 0.610 & 0.514 & 0.445 \\
\hline Organic matter ${ }^{2}$ & 0.887 & 0.918 & 0.910 & 1.75 & 0.453 & 0.368 & 0.366 \\
\hline Crude protein ${ }^{3}$ & 0.270 & 0.311 & 0.269 & 5.88 & 0.161 & 0.779 & 0.063 \\
\hline Ether extract ${ }^{3}$ & 0.077 & 0.225 & 0.266 & 8.75 & 0.002 & 0.001 & 0.097 \\
\hline Neutral detergent fiber ${ }^{2}$ & 0.967 & 0.934 & 0.935 & 1.43 & 0.174 & 0.105 & 0.314 \\
\hline Acid detergent fiber ${ }^{2}$ & 0.866 & 0.823 & 0.833 & 2.42 & 0.444 & 0.352 & 0.369 \\
\hline Digestible energy $^{2}$ & 0.846 & 0.873 & 0.856 & 2.73 & 0.688 & 0.746 & 0.422 \\
\hline
\end{tabular}

9 steers/treatment.

${ }^{1}$ Pooled standard error of treatment means.

${ }^{2}$ Expressed relative to total digestible nutrients

${ }^{3}$ Expressed relative to the total digested quantities that arrived at each compartment.

Table 4 - Effect of the treatments on the ruminal parameters and microbial synthesis efficiency and adjusted regression equations

\begin{tabular}{|c|c|c|c|c|c|c|c|}
\hline & \multicolumn{3}{|c|}{ Lipid level in the diet $(\mathrm{g} / \mathrm{kg})$} & \multirow{2}{*}{ SEM $^{1}$} & \multirow{2}{*}{$\mathrm{P}$} & \multicolumn{2}{|c|}{ Effect } \\
\hline & 20 & 40 & 60 & & & Linear & Quadratic \\
\hline \multicolumn{8}{|l|}{ Ruminal parameters } \\
\hline $\mathrm{pH}$ & 6.6 & 6.5 & 6.4 & 0.09 & 0.269 & $<0.001$ & $<0.001$ \\
\hline \multicolumn{8}{|l|}{ Volatile fatty acids, $\mathrm{mM} / \mathrm{L}$} \\
\hline Total volatile fatty acids & 121.3 & 122.2 & 116.2 & 4.02 & 0.316 & $<0.001$ & 0.219 \\
\hline Acetate & 70.2 & 71.0 & 68.3 & 3.00 & 0.576 & 0.348 & 0.469 \\
\hline Acetate:propionate ratio & 3.0 & 3.0 & 2.9 & 0.23 & 0.963 & $<0.001$ & 0.062 \\
\hline Microbial N flow (g/day) & 74.5 & 78.6 & 75.2 & 8.70 & 0.896 & 0.942 & 0.649 \\
\hline Efficiency of microbial Synthesis $\mathrm{g} N / \mathrm{kg}$ OMDR & 19.0 & 17.2 & 19.3 & 4.94 & 0.917 & 0.947 & 0.686 \\
\hline
\end{tabular}

9 steers/treatment.

OMDR - organic matter apparently digested in the rumen.

${ }^{1}$ Pooled standard error of treatment means. 
for 12 hours. These results indicate that the $\mathrm{pH}$ values obtained in the present study did not compromise ruminal fermentation. Furthermore, no significant differences in the synthesis of microbial protein among diets were observed (Table 4); thus, the pH did not affect microbial activity.

The concentration of $\mathrm{NH}_{3}-\mathrm{N}$ showed quadratic behavior $(\mathrm{P}=0.001)$ (Table 4); however, the trends in ruminal $\mathrm{NH}_{3}-\mathrm{N}$, as measured from $0,2,4,8$ and 12 hours post-feeding, were similar among treatments $(\mathrm{P}=0.06)$. Lower concentrations of ruminal $\mathrm{NH}_{3}-\mathrm{N}$ were observed in animals fed the diet containing $20 \mathrm{~g} / \mathrm{kg}$ lipids than in animals fed the 40 and $60 \mathrm{~g} / \mathrm{kg}$ lipid diets. Although the diets were not isonitrogenous, the protein intake for all diets was similar (Table 2).

At two hours after feeding, the concentration of $\mathrm{NH}_{3}-\mathrm{N}$ in the rumen was greater $(\mathrm{P}<0.05)$ than the $\mathrm{NH}_{3}-\mathrm{N}$ concentrations at 8 and 12 hours of post-feeding, which suggested that the protein sources in the rumen were degraded over time. Van Soest (1994) suggested that a ruminal $\mathrm{NH}_{3}-\mathrm{N}$ concentration below $13 \mathrm{mg} / \mathrm{dL}$ may affect the availability of nitrogen for microorganisms, which can compromise fiber ingestion and digestibility. Thus, the ruminal $\mathrm{NH}_{3}-\mathrm{N}$ concentration obtained from steers fed the $20 \mathrm{~g} / \mathrm{kg}$ lipid diet was below the suggested range. However, based on the other coefficients obtained from the $20 \mathrm{~g} / \mathrm{kg}$ lipid diet, no relationship between the concentration of $\mathrm{NH}_{3}-\mathrm{N}$ and the ruminal availability of fiber could be established.

The diet containing $60 \mathrm{~g} / \mathrm{kg}$ lipids in the DM presented the lowest $\mathrm{pH}$ values and the highest ammoniacal nitrogen content. Similar results were reported by Onetti et al. (2001), who studied the effect of the type and concentration of dietary fat on ruminal fermentation in dairy cattle. The cows were supplied with diets based on corn silage, and the results indicated that the addition of $40 \mathrm{~g} / \mathrm{kg}$ fat resulted in a higher $(\mathrm{P}<0.001)$ concentration of ammonia than the addition of $20 \mathrm{~g} / \mathrm{kg}$ fat. The authors attributed the observed increase in the ammonia concentration to a reduction in the use of ammoniacal nitrogen by cellulolytic bacteria (Table 4).

The rumen VFA concentration depends on the feed intake, feeding frequency and composition of the diet. The total VFA concentration and molar proportions of propionate and butyrate decreased linearly $(\mathrm{P}<0.001)$ when a diet containing $60 \mathrm{~g} / \mathrm{kg}$ lipids was supplied, compared with diets containing 20 and $40 \mathrm{~g} / \mathrm{kg}$ lipids (Table 4). Ruminal VFA was not affected by interaction $(\mathrm{P}=0.92)$ between treatments and sampling time. However, the rumen molar concentration of acetate was not affected by the lipid content of the diet. Therefore, the acetate to propionate ratio declined linearly when $60 \mathrm{~g} / \mathrm{kg}$ lipids were added to the diet, indicating that the lipid level affected ruminal fiber fermentation (Bateman \& Jenkins, 1998). Although changes were verified in ruminal VFA, no alterations were observed in total tract NDF digestibility. The large amounts of unsaturated oils fed to the animals were expected to interfere in ruminal fiber digestibility. The high fiber content of our diets might have promoted hydrolysis, which creates ideal conditions for rapid growth of the microbes that are responsible for the hydrolysis and hydrogenation of dietary fat, according to Jenkins (1993).

Similar to the present study, previous studies have suggested that the use of saturated and unsaturated lipids has a minor or insignificant effect on ruminal parameters, e.g., Harvatine \& Allen (2006). Bateman \& Jenkins (1998) observed that the VFA concentrations were 120.6, 125.9 and $123.4 \mathrm{mM}$ when 20,40 , and $60 \mathrm{~g}$ soybean oil $/ \mathrm{kg}$ were substituted for DM. These results are similar to those obtained in the current study, in which significant differences among lipid contents were observed.

The supply of vegetable oils frequently increases the efficiency of microbial synthesis. However, the effect of vegetable oils on microbial synthesis is not mediated by an increase in the fermentable energy content of the rumen. Vegetable oils reduce predation due to the defaunation effect of the oil (Dewhurst et al., 2000). Nevertheless, in the present study, the efficiency of microbial synthesis and duodenal flow of microbial $\mathrm{N}$ or dietary $\mathrm{N}$ were not significantly different $(\mathrm{P}>0.05)$ among treatments (Table 4$)$, and no defaunation effects (Table 5) from the lipid content were observed.

These results indicated that the populations of bacteria, fungi and protozoa were not affected by the dietary lipid content (Table 5). In general, fats are not a usable source of energy for anaerobic microorganisms, and they can inhibit microbial growth by altering the metabolic pathways of gram-positive bacteria. However, no significant differences in the responses to diets with different lipid contents were observed in the present study.

Ruminal microorganisms require an ideal environment for development, including a temperature between $38{ }^{\circ} \mathrm{C}$ and $40{ }^{\circ} \mathrm{C}$ and a $\mathrm{pH}$ of $5.5-7.0$ (Hoover, 1986). Thus, the conditions observed in this study may have favored microbial growth. The estimated total bacterial population varied from $1.99 \times 10^{12}$ to $1.74 \times 10^{12} / \mathrm{mL}$ of ruminal content, and a non-significant decrease $(\mathrm{P}>0.05)$ in the bacterial population was observed as the lipid content of the diet increased. According to the literature (Hungate, 1966; Olumeyan et al., 1986), the bacterial population in the rumen is large and diverse, and may vary between $10^{10}$ and $10^{12} / \mathrm{mL}$ of ruminal content. 
Table 5 - Average number of bacteria, fungi and ciliated protozoa in the rumen of steers supplemented with different lipid contents

\begin{tabular}{|c|c|c|c|c|c|c|c|}
\hline & \multicolumn{3}{|c|}{ Lipid level in the diet $(\mathrm{g} / \mathrm{kg})$} & \multirow{2}{*}{ SEM $^{1}$} & \multirow{2}{*}{$\mathrm{P}$} & \multicolumn{2}{|c|}{ Effect } \\
\hline & 20 & 40 & 60 & & & Linear & Quadratic \\
\hline \multicolumn{8}{|l|}{ Average population $/ \mathrm{mL}$} \\
\hline Bacteria $($ no. $\times 1012 / \mathrm{mL})$ & 2.0 & 1.7 & 1.6 & 0.28 & 0.553 & 0.292 & 0.929 \\
\hline Fungi (no. × $102 / \mathrm{mL}$ ) & 1.7 & 1.0 & 1.2 & 0.29 & 0.187 & 0.228 & 0.220 \\
\hline Total protozoa $($ no. $\times 105 / \mathrm{mL})$ & 9.9 & 7.9 & 9.6 & 2.85 & 0.796 & 0.939 & 0.505 \\
\hline Entodinium & 7.5 & 4.3 & 6.6 & 2.70 & 0.537 & 0.781 & 0.310 \\
\hline Epidinium & 1.8 & 2.2 & 1.8 & 0.65 & 0.826 & 0.980 & 0.544 \\
\hline
\end{tabular}

9 steers/treatment.

${ }^{1}$ Pooled standard error of treatment means.

In all of the treatment groups, protozoa from the genus Entodinium (Table 5) were found in relatively high quantities. Similar results were obtained by Valinote et al. (2005), who evaluated cottonseed and the calcium salts of fatty acids as sources of fat and determined the effects of monensin in cottonseed-based diets for beef cattle.

The predominance of the genus Entodinium in the rumen is consistent with the observations of other authors, who researched protozoan populations in cattle under different feeding conditions, such as diets rich in sugar cane (Franzolin \& Franzolin, 2000) or concentrate, diets with or without addition of fat (Towne et al., 1990), and the addition of ionophores to diets rich in forage or concentrate (Guan et al., 2006).

Several authors (Van Nevel \& Demeyer, 1988; Bonhomme, 1990; Chaudhary et al., 1995) have reported that ciliates have an effect on the degradation of structural carbohydrates, especially in diets containing high proportions of concentrate. In addition to the adhesion of lipids to feed particles and the toxic effect of fibrolytic bacteria, a reduction in the number of protozoa may reduce the extent of dietary fiber degradation when lipids are added to the diet of ruminants, especially when diets with high proportions of concentrate are supplied. Thus, because of the high proportion of fiber in the diet used in the present study, treatments with high lipid contents did not affect the microbial population.

\section{Conclusions}

Lipid supplementation of up to $60 \mathrm{~g} / \mathrm{kg}$ dry matter in the diet does not alter the intake of dry matter and nutrients or the microbial population of the rumen of steers. However, the addition of lipids reduces the ruminal $\mathrm{pH}$, the acetate: propionate ratio, the concentration of volatile fatty acids and the concentration of ammoniacal nitrogen, but it does not change the diet digestibility. Based on the similarity of the digestive profiles and the conditions of ruminal fermentation, lipid contents of 40 and $60 \mathrm{~g} / \mathrm{kg}$ may be added to the diet for Nellore steers.

\section{Acknowledgements}

The authors thank Fundação de Amparo à Pesquisa de São Paulo (FAPESP) for financing this research. BELLMAN Animal Nutrition supplied the supplement ingredients used during the whole experiment.

\section{References}

ASSOCIATION OF OFFICIAL ANALYTICAL CHEMISTY AOAC. Official methods of analysis. 16.ed. Arlington: AOAC International, 1995.

ALEXANDER, M. Most probable number method for microbial populations. In: PAGE, A.L.; MILLER, R.H.; KEENEY, D.R. (Eds.) Methods of soil analysis. 2.ed. Madson, WI.: ASA, SSSA, 1982. p.815-820.

BATEMAN, H.G.; JENKINS, T.C. Influence of soybean oil in high fiber diets fed to nonlactating cows on ruminal unsaturated fatty acids and nutrient digestibility. Journal of Dairy Science, v.81, p.2451-2458, 1998.

BERCHIELli, T.T.; ANDRADE, P.; FURLAN, C.L. Avaliação de indicadores internos em ensaios de digestibilidade. Revista Brasileira de Zootecnia, v.29, p.830-833, 2000.

BONHOMME, A. Rumen ciliates: their metabolism and relationships with bacteria and their hosts. Animal Feed Science and Technology, v.30, p.203-266, 1990.

BRYANT, M.P.; BURKEY, L.A. Cultural methods and some of the more numerous groups of bacteria in the bovine rumen. Journal of Dairy Science, v.3, p.205, 1953.

CECAVA, M. J.; MERCHEN, N.R.; GAY, L.C. et al. Composition of ruminal bacteria harvested from steers as influenced by dietary energy level, feeding frequency, and isolation techniques. Journal of Dairy Science, v.73, p.2480-2488, 1990.

CHAUDHARRY, L.C.; SRIVASTAVA, A.; SINGH, K.K. Rumen fermentation pattern and digestion of structural carbohydrates in buffalo (Bubalus bubalis) calves as affected by ciliate protozoa. Animal Feed Science and Technology, v.56, p.111- 117, 1995.

D'AGOSTO, M.T.; CARNEIRO, M.E. Evaluation of lugol solution used for counting rumen ciliates. Revista Brasileira de Zoologia, v.16, p.725-729, 1999.

DEHORITY, B.A.; TIRABASSO, P.; GRIFO JR., A.P. Most-probablenumber procedures for enumerating ruminal bacteria, including the simultaneous estimation of total and cellulolytic numbers in 
one medium. Applied and Environmental Microbiology, v.55, p.2789-2792, 1989.

DEMEYER, D.; DOREAU, M. Targets and procedures for altering ruminant meat and milk lipids. Proceedings of the Nutrition Society, v.58, p.593-607, 1999.

DEVETH, M.J.; KOLVER, E.S. Diurnal variation in $\mathrm{pH}$ reduces digestion and synthesis of microbial protein when pasture is fermented in continuous culture. Journal of Dairy Science, v.84, p.2066-2207, 2001.

DEWHURST, R.J.; DAVIES, D.R.; MERRY, R.J. Microbial protein supply from the rumen. Animal Feed Science and Technology, v.85, p.1-21, 2000.

DUCKETT, S.K.; GILLIS, M.H. Effects of oil source and fish oil addition on ruminal biohydrogenation of fatty acids and conjugated linoleic acid formation in beef steers fed finishing diets. Journal of Animal Science, v.88, p.2684-2691, 2010.

EIFERT, E.C.; LANA, R.P.; LANNA, D.P.D. et al. Consumo, produção e composição do leite de vacas alimentadas com óleo de soja e diferentes fontes de carboidratos na dieta. Revista Brasileira de Zootecnia, v.35, p.211-218, 2006.

ERWIN, E.S.; MARCO, G.J.; EMERY, E.M. Volatile fatty acid analyses of blood and rumen fluid by gas chromatography. Journal of Dairy Science, v.44, p.1768-1771, 1961.

FENNER, H. Method for determining total volatile bases in rumen fluid by steam distillation. Journal of Dairy Science, v.48, p.249-251, 1965.

FLUHARTY, F.L.; LOERCH, S.C.; DEHORITY, B.A. Effects of feed and water deprivation on ruminal characteristics and microbial population of newly weaned and feedlot-adapted calves. Journal of Animal Science, v.74, p.465-474, 1996.

FRANZOLIN, R.; FRANZOLIN, M.H. População de protozoários ciliados e degradabilidade ruminal em búfalos e bovinos zebuínos sob dieta a base de cana-de- açúcar. Revista Brasileira de Zootecnia, v.29, p.1853-1861, 2000.

FOX, D.G.; TYLUTKI, T.P.; TEDESCHI, L.O. et al. The net carbohydrate and protein system for evaluating herd nutrition and nutrient excretion. CNCPS version 5.0. New York, Ithaca: Cornell University, 2003. 237p.

GOERING, H.K.; VAN SOEST, P.J. Forage fiber analysis: apparatus reagents, procedures and some applications. Washington, D.C.: USDA, 1970. 379p. (Agricultural Handbook).

GORDON, G.L.R.; PHILLIPS, M.W. The role anaerobic gut fungi in ruminants. Nutrition Research Reviews, v.11, p.133-168, 1998.

GUAN, H.; WITTENBERG, K.M.; OMINSKI, K.H. Efficacy of ionophores in cattle diets for mitigation of enteric methane. Journal of Animal Science, v.84, p.1896-1906, 2006.

HARVATINE, K.J.; ALLEN, M.S. Effects of fatty acid supplements on ruminal and total tract nutrient digestion in lactating dairy cows. Journal of Dairy Science, v.89, p.1092-1103, 2006.

HESS, B.W.; MOSS, G.E.; HULE, D.C. A decade of developments in the area of fat supplementation research with beef cattle and sheep. Journal of Animal Science, v.86, p.E188-E204, 2008.

HOOVER, W.H. Chemical factors involved in ruminal fiber digestion. Journal of Dairy Science, v.69, p.2755-2766, 1986

HUNGATE, R.E. The rumen and its microbes. New York: Academic Press, 1966. 533p.

HUSSEIN, H.S.; MERCHEN, N.R.; FAHEY JR., G.C. Effects of forage level and canola seed supplementation on site and extent of digestion of organic matter, carbohydrates, and energy by steers. Journal of Animal Science, v.73, p.2458-2468, 1995.

JENKINS, T.C. Lipid metabolism in the rumen. Journal of Dairy Science, v.76, p.3851-3863, 1993.

JENKINS, T.C.; MCGUIRE, M.A. Major advances in nutrition: impact on milk composition. Journal of Dairy Science, v.89, p.1302-1310, 2006.

JENKINS, T.C.; WALLACE, R.J.; MOATE, P.J. et al. Board-invited review: Recent advances in biohydrogenation of unsaturated fatty acids within the rumen microbial ecosystem. Journal of Dairy Science, v.86, p.397-412, 2008.
MERTENS, D.R. Predicting in intake and digestibility using mathematical models of ruminal functions. Journal of Animal Science, v.64, p.1548-1558, 1997.

NAGARAJA, T.G.; NEWBOLD, C.J.; VAN NEVEL, C.J. et al. Manipulation of ruminal fermentation. In: HOBSON, P.N.; STEWART, C.S. (Eds.) Rumen microbial ecosystem. 2.ed. London: Blackie Academic and Professional, 1997. p.523-632.

NATIONAL RESEARCH COUNCIL - NRC. Nutrient requirements of beef cattle. 7.ed. Washington, D.C.: National Academy Press, 1996. 242p.

NATIONAL RESEARCH COUNCIL - NRC. Nutrient requeriments of dairy cattle. 7.rev.ed. Washinton, D.C.: 2001. 381p.

OLIVEIRA, S.G.; BERCHIELLI, T.T.; PEDREIRA, M. et al. Effect of tannin levels in sorghum silage and concentrate supplementation on apparent digestibility and methane emission in beef cattle. Animal Feed Science and Technology, v.135, p.236-248, 2007a.

OLIVEIRA, R.L.; ASSUNÇÃO, D.M.P.; BARBOSA, M.A.A.F. et al. Efeito do fornecimento de diferentes fontes de lipídeos na dieta sobre o consumo, a digestibilidade e o N-uréico plasmático de novilhos bubalinos em confinamento. Revista Brasileira de Zootecnia, v.36, p.733-738, 2007b.

OLUMEYAN, D.B.; NAGARAJA, T.G.; MILLER, G.W. et al. Rumen microbial changes in cattle fed diets with or without salinomycin. Applied and Environmental Microbiology, v.51, p.340-345, 1986.

ONETTI, S.G.; SHAVER, R.D.; MCGUIRE, M.A. et al. Effect of type and level of dietary fat on rumen fermentation and performance of dairy cows fed corn silage based diets. Journal of Dairy Science, v.84, p.2751-2759, 2001.

RELLING A. E.; REYNOLDS C. K. Feeding rumen-inert fats differing in degree of saturation decreases intake and increases plasma concentrations of gut peptides in lactating dairy cows. Journal of Dairy Science, v.90, p.1506-1515, 2007.

RUSSELL, J.B.; WILSON, D.B. Why are ruminal cellulolytic bacteria unable to digest cellulose at low pH? Journal of Dairy Science, v.79, p.1503-1509, 1996.

SENGER, C.C.D.; KOZLOSKI, G.V.; SANCHEZ, L.M.B. et al. Evaluation of autoclave procedures for fiber analysis in forage and concentrate feedstuffs. Animal Feed Science and Technology, v.146, p.169-174, 2008.

SNIFFEN, C.J.; O'CONNER, J.D.; VAN SOEST, P.J. et al. A net carbohydrate and protein system for evaluating cattle diets. II. Carbohydrate and protein availability. Journal of Animal Science, v.70, p.3562-3577, 1992.

TEMPELMAN, R.J. Experimental design and statistical methods for classical and bioequivalence hypothesis testing with an application to dairy nutrition studies. Journal of Animal Science, v.82, p.E162-E172, 2004.

TOWNE, G.; NAGARAJA, T.G.; BRANDT JR, R.T. et al. Ruminal ciliated protozoa in cattle fed finishing diets with or without supplemental fat. Journal of Animal Science, v.68, p.2150-2155, 1990.

USHIDA, K.; LASSALAS, B.; JOUANY, J.P. Determination of assay parameters for RNA analysis in bacterial and duodenal samples by spectrophotometry. Influence of sample treatment and preservation. Reproduction Nutrition Development, v.25, p.1037, 1985.

UEDA, K.; FERLAY, A.; CHABROT, J. et al. Effect of linseed oil supplementation on ruminal digestión in dairy cows fed diets with different forage:concentrate rations. Journal of Dairy Science, v.86, p.3999-4007, 2003.

VALINOTE, A.C.; NOGUEIRA FILHO, J.C.M.; LEME, P.R. et al. Fontes de lipídeos e monensina na alimentação de novilhos Nelore e sua relação com a população de protozoários ciliados do rúmen. Pesquisa Agropecuária Brasileira, v.41, p.117-124, 2006.

VAN NEVEL, C.; DEMEYER, D.I. Manipulation of rumen fermentation. In: HOBSON, H.D. (Ed.) The rumen microbial ecosystem. New York: Elsevier Science, 1988. p.387-443. 
VAN SOEST, P.J.; ROBERTSON, J.B.; LEWIS, B.A. Methods for dietary fiber, neutral detergent fiber and non-starch polysaccharides (NSP) in relation to animal nutrition. Journal of Dairy Science, v.74, p.3583-3597, 1991.

VAN SOEST, P.J. Nutritional ecology of the ruminant. Ithaca, NY: Cornell University Press, 1994. 476p.

WEISS, W.P.; PINOS-RODRIGUEZ, J. M. Production responses of dairy cows when fed supplemental fat in low- and highforage diets. Journal of Dairy Science, v.92, p.6144-6155, 2009.
ZINN, R.A.; OWENS, E.N. A rapid procedure for purine measurement and its use for estimating net ruminal protein synthesis. Canadian Journal of Animal Science, v.66, p.157-166, 1986.

ZINN, R.A.; PLASCENCIA, A. Influence of level and method of supplementation on the utilization of supplemental tallow fatty acids by feedlot steers. Journal of Animal Science, v.80 (Suppl. 1), p.270 (Abstr.), 2002.

ZINN, R.A.; GULATI, S.K.; PLASCENCIA, A. et al. Influence of ruminal biohydrogenation on the feeding value of fat in finishing diets for feedlot cattle. Journal of Animal Science, v.78, p.1738-1746, 2000. 